\title{
REKONSTRUKSI FOLKLOR BATAK TOBA DALAM BENTUK PERTUNJUKAN TORTOR SIGALE-GALE
}

\author{
RINI H. SINAGA \\ Prodi Pendidikan Tari
}

\begin{abstract}
This study aims to determine how the existence of folklore in Batak Toba society and pinpoint how "Reconstruction Folklore Batak Toba in the form Tortor performances Sigale-gale". For a discussion of the research objectives above, use the theories related to the research topic, such as the reconstruction theory, the theory of folklore, the theory of forms of performance, tortor understanding, and understanding existence. The research was conducted to discuss "Reconstruction Folklore Batak Toba In The Form Of Performing Tortor Sigale-gale" was conducted for 2 Months namely frontier in December 2015 to February 2016. The research is in the area of Pangururan Samosir and Medan Helvetia. The population in this study are some of the figures of young and old artists. The results using qualitative research methods include the presentation and interpretation of the data that is how "Reconstruction Folklore Batak Toba In The Form Of Performing Tortor Sigale-gale. Folklore (folklore) in the Toba Batak society is a kind of oral folklore and folklore instead of orally. Sigale-gale statue can move with the various movements that detail, such as hand movements up and down, rigid (staccato) and head could only shake his head. Reconstruction Folklore Sigale-gale lifted many of the artists into a work of art performances.Performances Tortor Sigale-gale one of the creativity of young people and parents are engaged in the arts.In the form of dance performances include the presence of motion, accompaniment, makeup, and clothing.
\end{abstract}

Keywords: Folklore, Tortor Sigale-gale, performances 


\section{PENDAHULUAN}

Keanekaragaman budaya atau cultural diversity adalah keniscayaan yang ada di bumi ini. Keanekaragaman budaya di Indonesia adalah sesuatu yang tidak dapat dipungkiri keberadaannya. Dalam konteks pemahaman masyarakat majemuk, selain kebudayaan kelompok suku bangsa masyarakat Indonesia juga memiliki berbagai kebudayaan daerah yang bersifat kewilayahan yang merupakan pertemuan dari berbagai kebudayaan kelompok suku bangsa yang ada di daerah tersebut.

Kebudayaan yang ada di daerah Sumatera Utara merupakan salah satu gugus kebudayaan yang ada di Indonesia sangat berpotensi untuk diamati. Budaya dalam setiap suku di Indonesia merupakan budaya yang diturunkan secara turun temurun dan dilestarikan dengan tetap melaksanakannya dalam kehidupan sehari-hari. Salah satunya adalah budaya pada suku Batak yang merupakan suku yang hidup dan berkembang di Provinsi Sumatera Utara.

Di Sumatera Utara suku Batak memiliki etnik dari sekian banyak rumpun Batak. Dari sekian rumpun Batak ada enam etnis suku Batak yang ada di Sumatera Utara yang terdiri dari Batak Simalungun, Batak Karo, Batak Pakpak Dairi, Batak Mandailing, Batak Tapanuli
Tengah (pesisir sibolga), dan Batak Toba. Semua etnis memiliki nilai budaya masing-masing, mulai dari adat istiadat, tari daerah, jenis makanan, budaya, cerita rakyat, dan pakaian adat juga bahasa daerah masing-masing. Keragaman budaya sangat mendukung dalam pasar pariwisata di Sumatera Utara. Salah satu bentuk dari kebudayaan itu adalah kesenian. Suku Batak Toba memiliki kesenian seperti seni musik, seni tari, seni rupa, seni drama/teater, seni sastra dan juga seni kerajinan tangan. Suku Batak Toba adalah salah satu ragam suku yang ada di Sumatera Utara yang masih menyimpan sejarah dan masih sangat kental dengan adat serta kebudayaannya.

Batak Toba memiliki Tortor, danau Toba, megalitik (kubur batu), legenda (cerita rakyat), adat budaya yang bernilai tinggi sebagai aset wisata. Cerita rakyat suku Batak Toba banyak diangkat para seniman sebagai sumber ide karya seni pertunjukan. Cerita rakyat yang ada di Batak Toba seperti terjadinya Danau Toba, Siboru Pareme, Boru Tumbaga, Tunggal Panaluan, Sigale-gale, Batu Gantung, Batu Kursi, dan Kuburan Raja Sidabutar.

Bentuk pertunjukan yang diciptakan para seniman bermacammacam, seperti sendratari, dramatari, teater rakyat/opera Batak dan karya tari 
sebagai karya-karya kreatif seniman Toba dalam mengusung cerita yang bersumber dari Folklor Batak. Salah satu cerita yang akan penulis angkat menjadi fokus penelitian ini adalah Rekonstruksi Folklor Batak Toba dalam bentuk pertunjukan TortorSigale-gale.

Berdasarkanpernyataandiatas, yang menjadi tujuan dalam penelitian ini adalah: "Mendeskripsikan keberadaan Folklor pada masyarakat Batak Toba dan mendeskripsikan Rekonstruksi Foklor Batak Toba dalam bentuk pertunjukan Tortor Sigale-gale.

\section{Landasan Teori}

Untuk membahas Rekonstruksi Folklor Batak Toba dalam bentuk pertunjukanTortorSigale-gale, makapenulismenggunakanteoriStudiKom paratifdariSuprantosebagaiteoriutamadanj ugateoriBentukPertunjukandariLangerda nteoriFolklor dari Dananjaja.

\section{Lokasi dan Waktu Penelitian}

Sesuai dengan judul penelitian (Rekonstruksi Folklor Batak Toba dalam bentuk pertunjukan Tortor Sigalegale)maka penelitian dilaksanakan di Sanggar Angel Elkanean Kabupaten Samosir Waktu penelitian dilaksanakan pada bulanDesember 2015hinggabulanFebruari 2016.

\section{Populasi dan Sampel}

Populasi

Populasi

dalam

penelitianiniadalahparasenimandantokohtokoh budaya masyarakat.

\section{Sampel}

Sampel dalam penelitian ini adalah 2 orang yang merekonstruksidan yang mengetahuidanterlibatdalam bentuk pertunjukan Tortor Sigale-gale.

\section{Teknik Pengumpulan Data}

Teknik pengumpulan data yang dilakukan adalah sebagai berikut:

1. Studi kepustakaan

2. Observasi

3. Wawancara

4. Dokumentasi

\section{Teknik Analisis Data}

Dalam penelitian ini data yang digunakan adalah analisis deskriptif kualitatif dimana penelitian ini sesuai dengan fakta sosial dan memberi gambaran, keterangan serta uraian.

\section{ISI}

\section{MasyarakatBatak Toba}

Batak Toba merupakan suku yang paling banyak jumlahnya. Dari berbagai studi kita dapat menemukan bahwa suku Batak terdiri dari enam sub-suku bahkan 
ada beberapa penulis yang menambahkan bahwa orang Alas, Gayo, orang Pardembang yang ada di pesisir sungai Asahan, sebagian orang pesisir yang tinggal di Pantai Barat Pulau Sumatera juga keturunan orang Batak lihat Pederson, Niessen, Tobing, Pasaribu dalam Purba, M (2004:6) tetapi dalam kehidupan sehari-hari kata "Batak" itu sendiri diartikan kepada suku Batak Toba.

Orang Batak Toba, baik secara pribadi maupun secara kelompok mengakui ada kuasa di luar kuasa manusia. Pengakuan demikian nyata benar dalam kehidupan sehari-hari adanya hasrat manusia menyerahkan diri kepada kuasa. Pada mulanya keagamaan orang Batak adalah konsep totalitas dimana komunitas, pribadi dan sebagainya terjalin dalam satu pandangan. Konsep totalitas ini tercermin dalam pembagian alam menjadi tiga bagian dan Mulajadi Na Bolon sebagai penguasa (Tobing 1956:58). Konsep Tuhan Yang Maha Tinggi disebut Partaganing. "Tuhan" itu secara fungsional terbagi atas tiga unsur dalam prinsip yang tri tunggal yaitu : tuan bubi na bolon, ompu silaon na bolon dan tuan pane na bolon yang secara berturut-turut menguasai banua ginjang (benua atas: langit), banua tonga (benua tengah: bumi), dan banua toru (benua bawah: laut dan cahaya) (pasaribu 1986:50).

Konsep Tuhan yang sedemikian itu menurut para ahli antropologi religi adalah akibat dari pengaruh hindu yang menyusup ke dalam kepercayaan asli orang Batak (Parkin 1956:28). Selain itu masyarakat Batak juga percaya bahwa Roh dan jiwa mempunyai kekuatan. Itulah sebabnya setiap bahasa mengenai budaya Batak sejak dahulu sampai sekarang harus berkaitan dengan sejarah falsafah hidup berdasarkan animisme. Masyarakat Batak Toba masih percaya dengan adanya Roh dan Jiwa, sehingga masyarakat Batak Toba percaya bahwa dalam patung Sigale-gale ada Roh anak Raja.

Kesenian dalam masyarakat Batak Toba adalah : Vokal, musik Insrumental, Gondang Hasapi, Sabangunan, Instrumen Tunggal, Seni Rupa, Seni Sastra, Seni Tekstil, dan Seni Tari.

\section{Keberadaan Folklor pada masyarakat Batak Toba}

orang Batak Toba mengakui kehidupan sosial mereka tidak terlepas dari kebudayaan yang dimiliki. 
Masyarakat yang berbudaya hidup dari berbagai faktor yang menentukan cara kehidupan masyarakat. Dalam masyarakat Batak Toba adat dalam kehidupan sehari-hari merupakan wujud dari sistem nilai kebudayaan yang dijunjung tinggi. Adat sendiri adalah istilah yang sering digunakan di Indonesia, adat merujuk pada segala hal yang dari alam yang mengikuti cara sendiri yang khas. Adat memiliki asalusul keillahian dan merupakan seperangkat seperangkat norma yang diturunkan dari nenek moyang yang berulang-ulang atau yang teratur datang kembali, lalu kembali menjadi suatu kebiasaan atau hal yang biasa.

Ada pun jenis-jenis Folklor pada masyarakat Batak Toba adalah jenis Folklor lisan dan Folklor bukan lisan. Folklor atau cerita lisan banyak terdapat di daerah Batak Toba, Seperti halnya keberadaan Folklor pada masyarakat Batak Toba yang di temukan adalah Folklor ungkapan, bahasa rakyat, cerita prosa (legenda), tarian rakyat, dan nyanyian rakyat. Sedangkan Folklor bukan lisan terdapat di daerah Batak Toba adalah arsitektur Rumah Adat Batak Toba, Kerajinan tangan rakyat,Pakaian/perhiasan tradisional, Obat-obatan tradisional, Masakan/minuman tradisional, dan Gorga Batak Toba.

Folklor ungkapan lisan sering diucapkan orang pada upacara adat atau saat berbincang-bincang, saat melakukan kritik atau nasihat kepada orang kedua atau ketiga. Isi ungkapan Folklor lisan merupakan nasihat, kiasan, cerita atau kritik tajam. Folklor menjadi simbol demokrasi Batak. Cerita prosa rakyat (legenda) merupakan Folklor yang mengungkapkan kejadian nyata, atau cerita berbasis pengalaman yang anonim, tetapi berkembang luas ditengah masyarakat yang mengandung teladan, nasihat dan juga larangan. 
Rekonstruksi Folklor Batak Toba dalam bentuk pertunjukan Tortor Sigale-gale

Cerita Sigale-gale yang banyak diangkat para seniman menjadi sebuah pertunjukan tari. Pertunjukan Tortor Sigale-gale merupakan salah satu kreativitas para kaula muda atau tua yang bergerak dibidang seni. Dimana dalam pertunjukan ini para seniman mengangkat kembali sejarah dari bangsa Batak. Dari banyaknya sejarah orang Batak yang ada para seniman tertarik mengangkat Sigalegale menjadi sebuah bentuk pertunjukan tari (Tortor). Pertunjukan merupakan bentuk seni yang cukup kompleks karena merupakan gabungan antara bidang seni.

Dengan berkembangnya zaman para seniman membuat ide kreatif untuk mengembangkan Tortor Sigale-gale dan mengangkatnya ke dunia hiburan atau entertainment. Seniman kreatif yang sudah merekonstruksi Folklor Batak Toba mengangkat cerita Sigale-gale oleh Sanggar Angel Elkanean dalam bentuk pertunjukan. Dalam bentuk pertunjukan dapat dilihat dari :

\section{a. Gerak}

Patung Sigale-gale dapat bergerak dengan berbagai gerakannya yang detail, seperti gerakan tangan yang naik turun, kaku (stakato) dan kepala hanya bisa geleng-geleng. Selanjutnya oleh senimanseniman kreatif mengembangkan gerak tersebut dalam bentuk peretunjukan yang diberi nama Tortor Sigale-gale. Dalam Tortor Sigale-gale yang direkonstruksi oleh Marlita Simbolon di Sanggar Angel Elkanean tidak terlepas dari gerak-gerak dasar Tortor Batak Toba yang sudah dikembangkan dan Tortor Sigale-gale yang direkonstruksi menggunakan orang sebagai Sigale-gale.

\section{b. Iringan Musik Tortor Sigale- gale}

Secara tradisional antara musik dan tari sangat erat hubungannya. Keduanya berasal dari hal yang sama yakni dorongan atau naluri ritmis manusia. Seperti yang kita ketahui bahwa musik merupakan partner yang tidak dapat dipisahkan dari tari. Keduanya saling isi mengisi dan merupakan perpaduan yang harmonis.

Dalam bentuk pertunjukan Tortor Sigale-gale yang telah di Rekonstruksi oleh Sanggar Angel Elkanean menggunakan iringan musik lagu, seperti Gondang Lapian, Satu Tiga, Sihutur Sanggul dan Sappe Tua.

\section{c. Tata Rias}

Tata rias merupakan salah satu unsur yang dapat menunjang sebuah tarian agar menjadi lebih kuat. Tata rias 
lebih ditekankan pada wajah dan rambut. Rias tidak hanya sekedar membuat seorang penari menjadi cantik dan tampan , namun dapat membantu mewujudkan ekspresi penari sesuai peran yang dibawakannya.

Tata rias yang digunakan adalah rias cantik dan rias tokoh/watak. Rias watak ini mendukung watak seseorang dengan karakter yang diperankan sehingga dapat membedakan tokoh yang satu dengan tokoh yang lain. Dalam pertunjukan Tortor Sigale-gale ini adalah rias cantik dan rias watak.

\section{d. Tata Busana}

Busana merupakan pendukung dalam sebuah pertunjukan dan masuk kedalam unsur-unsur dalam penyajian sebuah tari. Busana dalam tari harus menunjang tema suatu tarian yang mampu membantu ungkapan tari tanpa menghambat dan mengurangi tari. Pada tarian tradisonal busana yang digunakan sangat sederhana sekali, tetapi tetap mempunyai konsep yang sesuai.

Pada jaman dahulu sebelum orang batak mengenal tekstil buatan luar, ulos adalah pakaian sehari-hari. Bila dipakai laki-laki bagian atasnya disebut handehande sedangkan bagian bawah disebut singkot kemudian bagian penutup kepala disebut tali-tali. Bila dipakai perempuan, bagian bawah hingga batas dada disebut haen (abit) untuk penutup pungung disebut hoba-hoba dan bila dipakai berupa selendang disebut ampe-ampe dan yang dipakai sebagai penutup kepala disebut saong.

Dengan berkembangnya zaman, setelah orang mengenal tekstil buatan orang luar, sekarang kostum yang dipakai dalam sebuah pertunjukan sudah menggunakan kebaya dan bahan-bahan tekstil yang lain dengan berbagai model sesuai selera. Biasanya dalam pemakaian busana tari selalu di lengkapi dengan assesoris seperti, kalung, gelang, tusuk konde, mahkota, topi dan sebagainya.

DalampertunjukanTortorSigalegale ini perempuannya menggunakan busana bagian atas dengan baju berwarna dan bagian bawah menggunakan rok yang dibuat dari bahan ulos Sadum berwarna merah dan hande-hande yang dipakai perempuan juga ulos Sadum berwarna merah. sedangkan laki-lakinya bagian atas memakai baju ulos Ragi Hotang dan menggunakan celana.

\section{PENUTUP}

\section{Kesimpulan}

Dari hasil penelitian dan pembahasan mengenai Rekonstruksi Folklor Batak Toba dalam bentuk pertunjukan Tortor Sigale-gale, yang 
telah dideskripsikan pada bab sebelumnya, maka diperoleh kesimpulan sebagai berikut:

1. Seniman-seniman kreatif membuat atau menciptakan karya-karya yang kerap sekali mengangkat sumber idenya dari cerita-cerita yang ada menjadi bentuk pertunjukan. Bentuk pertunjukan yang diciptakan para seniman bermacam-macam. Dalam bentuk pertunjukan seperti sendratari, dan karya tari yang merupakan karya-karya kreatif seniman Toba mengusung cerita yang bersumber dari Folklor Batak. Salah satunya adalah cerita Sigale-gale.

2. Folklor merupakan sebagian kebudayaan yang penyebarannya melalui tutur kata atau lisan disebut sebagai tradisi lisan. Tradisi lisan mencakup cerita rakyat, teka-teki, peribahasa, nyanyian rakyat, tarian rakyat, dan arsitektur rakyat. Folklor yang diwariskan secara turuntemurun disebut juga sebagai cerita rakyat. Rekonstruksi foklor dalam bentuk karya seni pertunjukan merupakan bagian dari kreativitas seniman. Foklor Batak memiliki banyak nilai-nilai dan pesan moral yang disampaikan melalui tradisi lisan. Dari folklor Batak Toba seniman banyak terinspirasi untuk membuat seni pertunjukan. Banyak karya seni pertunjukan yang lahir dari foklor.

3. Rekonstruksi Folklor Sigale-gale yang banyak diangkat para seniman menjadi sebuah pertunjukan tari. Pertunjukan Tortor Sigale-gale merupakan salah satu kreativitas para kaula muda atau tua yang bergerak dibidang seni. Dimana dalam pertunjukan ini para seniman mengangkat kembali sejarah dari Bangso Batak. Dalam hal ini para seniman merekonstruksi folklor Sigale-gale ke dalam bentuk pertunjukkan tari. Tortor Sigalegale ini berasal dari daerah Samosir yang sering dipertunjukan di museum Simanindo dan Tomok dengan memainkan boneka Sigale-gale. Dengan berkembangnya zaman para seniman membuat ide kreatif untuk mengembangkan Tortor Sigale-gale dan mengangkatnya ke dunia hiburan atau entertainment. Seniman kreatif yang sudah merekonstruksi 
Folklor Batak Toba mengangkat cerita Sigale-gale dalam bentuk pertunjukan.

4. Dalam pertunjukan Tortor Sigalegale ini perempuannya menggunakan busana bagian atas dengan kebaya dan bagian bawah menggunakan rok yang dibuat dari bahan ulos Sadum berwarna merah dan hande-hande yang dipakai perempuan juga ulos Sadum. sedangkan laki-lakinya bagian atas mengunakan baju atau jubah.

5. Pada kehidupan masyarakat Batak Toba tortor dan musik gondang ibarat koin yang tidak bisa dipisahkan, hal ini sesuai dengan pepatah Batak mengatakan " didia adong gondang disi adong tortor" yang artinya Dimana terdengar gondang disitulah terdapat tortor. Hal tersebut menyebabkan tortor selalu tampil bersama gondang dan begitu sebaliknya. Gondang yang menjadi iringan musik pada Tortor Sigale-gale ini dapat dimainkan dengan mennggunakan ansambel Gondang Sabangunan dan Gondang Hasapi.

\section{Saran}

Dari kesimpulan diatas, peneliti mengajukan beberapa saran, antara lain:

1. Dengan adanya seniman mengangkat Rekonstruksi Folklor Batak Toba kedalam bentuk pertunjukan semoga masyarakat dapat menghargai dan mendukung setiap karya-karya yang dilaksanakan oleh para seniman khususnya seniman Batak.

2. Kegiatan pertunjukan yang mengangkat kembali budaya dan sejarah batak patut dipertahankan seniman

3. Pemerintah perlu memperhatikan seniman yang kreatif di Sumatera Utara 


\section{DAFTAR PUSTAKA}

Adi, Prasetijo. 2009. Keragaman Budaya Indonesia. Jakarta: Etno Budaya

Bungin, Burhan. 2011. Penelitian Kualitatif. Jakarta: Kencana.

Djelantik, AAM. 1990. Pengantar Pasar Estetika. Denpasar: STSI Denpasar

1999. Estetika. Bandung:

Masyarakat Seni Pertunjukan Indonesia.

Dyastriningrum. 2009. Antropologi Kelas

XII. Jakarta : Pusat Perbukuan, Departemen Pendidikan Nasional.

Gultom, Ibrahim. 2010. Agama Malim di Tanah Batak. Jakarta: Bumi Aksara.

Hadeli. 2006. Pedoman Penelitian Kuantitatif. Jakarta: Kencana.

Hidayat. 2007. Metode Penelitian Kuantitatif. Jakarta

Langer, Susanne K. 1998. Rout-Ledge Encyclopedia Of Philosophy. London

Marbun, B.N. 1996, Kamus Politik. Jakarta:Pustaka Sinar Harapan.

Maryaeni. 2005. Metode Penelitian Kebudayaan. Jakarta: Bumi pustaka.

Merriam, Alan P. 1964. The Anthopology Of Music. Evanston Illinois: North Western University Press.

Mspi. 1997. Pertunjukan Perjalanan. Bandung
Nurwani, 2008, Diktat Pengetahuan Tari. Unimed: Medan

Peter, dkk. 2009. Kebudayaan Tradisional. Jakarta: LSPP

Situmorang, Jaulahan. 1992. Penuntun Adat Praktis. Pematang Siantar.

Soedarsono. 1990. Tinjauan Seni Sebuah Pengantar untuk Apresiasi Seni.Yokyakarta: Saku Dayar Sana.

1999. Seni Pertunjukan

Indonesia di Era Globalisasi. Jakarta: Direktorat Jenderal Pendidikan Tinggi Departemen Pendidikan dan Kebudayaan.

Sophar. 2015. Folklor Batak Toba. Jakarta: Obor.

Sugiyono. 2008. Metode Penelitian Kuantitatif dan $R \& D$. Bandung: Alfabeta. 2009. Metode Penelitian Kuantitatif dan $R \& D$. Bandung: Alfabeta.

2010. Metode Penelitian Kuantitatif dan $R \& D$. Bandung: Alfabeta.

Supranto. 2004. Metodologi Penelitian Kependidikan.Bandung:

PublishingHouse.

Suyanto, dkk. Metodologi Penelitian Sosial. Jakarta: Kencana.

Tambunan, Emil H. 1982. Sekelumit Mengenai Masyarakat Batak Toba dan Kebudayaan. Bandung : Tarsito 
(http://dwichandrawaskita10.blogspot.co. id/2013/03/misteri-patung-sigale-galeyang-bisa.html) http://kebudayaankesenianindonesia.blog spot.co.id/2012/06/suku-batak-toba-diprovinsi-sumatera $1739 . \mathrm{html}$

http://www.negerikuindonesia.com/2015/

$\underline{12 / \text { tari-sigale-gale-kesenian- }}$

$\underline{\text { tradisional.html }}$

http://kebudayaankesenianindonesia.blog spot.co.id/2012/06/folklore-bukan-lisan$\underline{\text { arsitektur-rumah.html }}$

http://serbasejarah.blogspot.com/2011/12 /peran-folklore-mitologi-legendadan.html 